
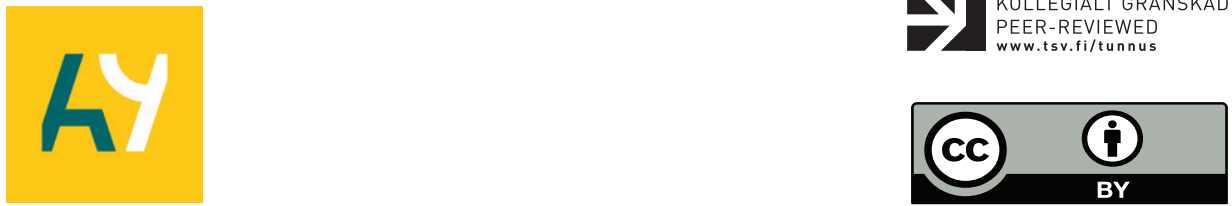

Maarit Särkilahtia ${ }^{a}$ Kaisa Mustajärvi ${ }^{b}$, Salla Leppänen

\title{
Biosuodattimia, hevoshakoja ja viherkattoja - yhdessä oppiminen luontopohjaisten ratkaisujen luomisessa
}

\section{Mutual learning about Nature-based Solutions - co-creation of biofilter, paddock and green roof}

This article explores mutual learning as part of a process of co-creating nature-based solutions - a biofilter, a green roof, and a horse park. Nature-based solutions are located in Tampere and are part of the EU project Unalab. The research has been conducted from within the pilot project and it has focused on concrete situations of learning. This study confirmed that mutual learning is the most important achievement of co-creation and should be clearly set also as a goal of co-creation. Creating a shared vision is important in the early stages of a project. Mutual learning enhances equality between participants and creates space for managing the complexity of nature-based solutions. If co-creation focuses too much on practical implementation planning instead of learning, the views of the experts will be emphasized and the citizens' views will remain marginal. Many urban actors also have the capacity to design nature-based solutions, but this requires more targeted methods of co-creation. The best progress was made when co-creating with a small and flexible group from the city, together with key stakeholders of the demonstration. Site visits and personal conversations developed a common will and commitment. In large planning groups, negotiations between institutions made implementation difficult.

Keywords: nature-based solution, mutual learning, co-creation, urban living lab

\section{Johdanto}

Parhaimmillaan luontopohjaiset ratkaisut kokoavat toimijoita yhteen vastaamaan ilmastonmuutoksen ja kaupungistumisen tuottamiin ongelmiin (Eggermont ym. 2015; Maes \& Jacobs 2017). Käytännössä kaupunkiluonnon merkityksestä ei kuitenkaan ole yhteistä näkemystä vaan kasvavien ja tiivistyvien kaupunkien rakentamispaineet uhkaavat luonnontilaisia alueita ja luontopohjaiset ratkaisut nähdään usein kustannuskysymyksenä. "Erilaisten maankäytön paineiden kobdistuessa samoille alueille keskiöön nousee kysymys, minkälaisilla

\footnotetext{
${ }^{a}$ Kaupunkiympäristön palvelualue, Tampereen kaupunki ja

Tekniikan ja luonnontieteiden tiedekunta, Tampereen yliopisto, maarit.sarkilahti@tuni.fi

${ }^{\mathrm{b}}$ Environment \& Health, Ramboll Finland Oy, Tampere

${ }^{\mathrm{c}}$ Kaupunkiympäristön palvelualue, Tampereen kaupunki
} 
arvoilla ja visioilla, minkälaisen kokonaissunnittelun pobjalta ja kenen ebdoilla kaupunkia rakennetaan." (Paloniemi 2019b, 141).

Kaupunkien luontopohjaiset ratkaisut lähtevät liikkeelle usein kunnan aloitteesta, mutta niiden suunnitteluun ja toteutukseen tarvitaan eri toimijoiden yhteistyötä (Frantzeskaki 2019). Yhteiskehittäminen on tarpeen, koska tiiviissä kaupunkirakenteessa yhdellä ratkaisulla tavoitellaan monia erilaisia hyötyjä, kuten viilennystä, sade- ja sulamisvesien hallintaa, luonnon monimuotoisuuden vaalimista ja ihmisten hyvinvointia (Eggermont ym. 2015). Luontopohjaiset ratkaisut tuottavat hyötyjä ja mahdollisesti myös haittoja (Raymond ym. 2017) monille eri sidosryhmille, joiden näkemyksiä tulee huomioida ratkaisujen kehittämisessä. Lisäksi ratkaisujen monet hyödyt ja luonnon ekosysteemeihin perustuva toiminta tekevät luontopohjaisista ratkaisuista monimutkaisia, minkä vuoksi niiden hallintaan tarvitaan monialaista osaamista. Monialaiset työryhmät ja aito yhteiskehittäminen ovat kuitenkin käytännössä harvinaisia, koska eriävät tavoitteet koetaan kaupunkisuunnittelun hidasteiksi (Raymond ym. 2017).

Julkishallinnon tutkimuksessa yhteiskehittäminen (co-creation) ja yhteistuotanto (co-production) määritellään kansalaisten ja julkisen sektorin ammattilaisten yhteiseksi ponnistukseksi parantaa julkisia palveluita (Brandsen ym. 2018). Voorberg ym. (2015) täsmentävät määrittelyä erottelemalla kolme kansalaisten roolia: 1) osallistuminen sellaisten palveluiden toteutukseen, joista on aiemmin vastannut julkinen sektori, 2) osallistuminen palvelun sisällön ja prosessin muotoiluun ja 3) aloitteen tekeminen uudesta palvelusta. Näistä palvelun toteutus on yhteistuotantoa, kun taas yhteiskehittäminen viittaa muotoiluun ja aloitteen tekemiseen. Yhteiskehittäminen voi kohdistua ydin- tai täydentävään palveluun (Brandsen $y m$. 2018), mikä on osuva tarkennus monihyötyisten luontopohjaisten ratkaisujen tapauksessa.

Yhteiskehittämiselle on annettu edellistä laajempi tulkinta kokeilujen ja elävien laboratorioiden yhteydessä. Elävät laboratoriot (urban living labs), joihin tämäkin tutkimus tukeutuu, ovat kaupungissa sijaitsevia rajattuja tiloja kokeiluihin ja oppimiseen perustuvan tiedon ja innovaatioiden yhteiskehittämistä varten (Puerari ym. 2018). Niissä yhteiskehittämiseen osallistuvat keskeiset sidosryhmät, kuten paikalliset yritykset, julkinen sektori, yliopistot ja kansalaiset (Chronéer ym. 2019; Puerari ym. 2018). Tämä laaja tulkinta yhteiskehittämisestä useiden sidosryhmien välillä sopii kaupunkien monitahoisten ongelmien luontopohjaiseen ratkomiseen. Tässä artikkelissa käytämme yhteiskehittämisen käsitettä eläviä laboratorioita koskevaa kirjallisuutta mukaillen kuvaamaan laajasti julkisen palvelun, eli tässä tapauksessa luontopohjaisen ratkaisun, ideointia ja muotoilua yhdessä sidosryhmien kanssa. Yhdessä oppiminen on tässä tärkeä tavoite (Puerari ym. 2018).

Tämä tutkimus on tehty osana Urban Nature Labs -projektia (Unalab) ja Euroopan unionin Horisontti 2020 -ohjelman käynnistämää luontopohjaisten ratkaisujen laajamittaista kokeilua eurooppalaisissa kaupungeissa. Tampere on yksi kohdekaupungeista ja sen tavoitteena projektissa on kehittää luontopohjaista hulevesien hallintaa. Tavoitteena on myös hallinnon kehittäminen luontopohjaisia ratkaisuja mahdollistavaan suuntaan ja uutena työkaluna kokeillaan yhteiskehittämistä, johon keskitymme tässä artikkelissa. Tutkimme yhteiskehittämisen prosessia ja kolmea siinä muovautuvaa kokeilua Tampereella: biosuodatinta, viherkattoa ja hevoshakaa. Nämä valittiin tutkimuskohteiksi, koska ne valottavat yhteiskehittämisen eri puolia, kuten toimijoiden erilaisia rooleja ja idean muovautumista erilaisissa kohtaamisissa. Samalla kokeilumme kuvaavat luontopohjaisten ratkaisujen laajaa kirjoa jo yhdessä projektissa.

Olemme osallistuneet projektin käytännön toteutukseen ja arvioimme yhteiskehittämisen onnistumisia ja epäonnistumisia projektin sisältä käsin. Pyrimme lisäämään ymmärrystä yhteiskehittämisen tavoitteista (Voorberg ym. 2015), yhdessä oppimisesta (Puerari ym. 2018) ja luovista menetelmistä (Frantzeskaki 2019). Näistä puuttuu sekä tutkimustietoa että käytännön osaamista. Tutkimuskysymyksemme ovat: 1) Miten yhteiskehittäminen palvelee yhdessä oppimista luontopohjaisten ratkaisujen 
suunnittelussa ja toteutuksessa? 2) Minkälaiset menetelmät sopivat luontopohjaisten ratkaisujen yhteiskehittämiseen? Luontopohjaisten ratkaisujen toteuttajat voivat hyödyntää analyysimme tuloksia yhteiskehittämisen tavoitteiden asettamisessa, menetelmien valinnassa ja sidosryhmäkartoituksessa sekä projektiluontoisen pilotoinnin ja yhteiskehittämisen yhdistämisessä pitkän aikavälin kaupunkikehitykseen. Artikkelin avulla osallistumme yhdessä oppimista, yhteiskehittämistä ja eläviä laboratorioita koskevaan tieteelliseen keskusteluun, joka on alkanut viritä myös Suomessa (Leminen ym. 2017).

\section{Miksi ja miten pitäisi yhteiskehittää?}

Voorberg ym. (2015) tarkastelevat julkisten palveluiden yhteiskehittämistä ja toteavat yhteiskehittämisen olevan usein itseisarvo, jolloin kysytään virheellisesti "miten pitäisi yhteiskehittää" ja tärkeä kysymys "miksi pitäisi ybteiskehittää" unohtuu.

Puerari ym. (2018) tarjoavat kattavan vastauksen "miksi”-kysymykseen: yhteiskehittämisen tavoitteena on tehdä ja/tai oppia yhdessä olipa kohteena sitten luontopohjainen ratkaisu tai muu innovaatio. Yhdessä tehden pyritään kohti innovaatiota, joka voi olla palvelu, prosessi tai tuote. Yhdessä oppiminen taas on laajempi kokonaisuus, jossa lisätään tietoa, opitaan toisilta ja verkostoidutaan. Oppiminen on sidoksissa myös yhtä innovaatiota laajempaan sosio-tekniseen muutokseen ja siihen ajatukseen, että osallistumisella on itseisarvo. Usein yhteiskehitettäessä sekä tehdään että opitaan yhdessä, mutta paino on enemmän toisella (Puerari ym. 2018). Vuorovaikutuskokemukset ja yhdessä oppiminen sekä yhteinen arvon luominen voidaan nähdä merkittävämpinä yhteiskehittämisen tuloksina kuin syntynyt tuote (Kujala ym. 2019; Prahalad \& Ramaswamyn 2004).

Luontopohjaisten ratkaisujen yhteydessä yhteiskehittämisen tavoitteiksi on nostettu lisäksi monimutkaisuuden hallinta ja eri tavoitteiden huomioiminen (Nesshöver ym. 2017; Raymond ym. 2017), luontosuhteen kehittyminen (van den Bosch \& Ode Sang 2017) ja ratkaisujen yhdistäminen kaupunkielämään (Frantzeskaki 2019). Luontopohjaisilla ratkaisuilla voidaan yhdistää toimijoita ja osallistaa kansalaisia ilmastonmuutokseen sopeutumiseen, koska luontopohjaisilla ratkaisuilla saavutettavat monet hyödyt edistävät niiden hyväksyttävyyttä. Eri tavoitteita yhdistämällä voidaan lisäksi kytkeä vaativampia tavoitteita tutumpiin (Brink \& Wamsler 2018). Luontopohjaisten ratkaisujen hyödyt yhdistävät toimijoita myös kaupungin sisällä eri hallintokuntien välillä (Frantzeskaki 2019).

Yleensä julkisen sektorin odotetaan parantavan yhteiskehittämistä (Voorberg ym. 2015), mutta myös kansalaisyhteiskunnan puolella tarvitaan avoimuutta yhteistyöhön kaupungin kanssa ja ammattimaisten yhteistyötapojen kehittämistä (Frantzeskaki 2019). Omistajuuden tunne on edellytys yhteiskehittämiseen sitoutumiselle (Puerari ym. 2018). Kansalaisten tietoisuus, arvot ja sosiaalinen pääoma vaikuttavat yhteiskehittämisen onnistumiseen (Voorberg ym. 2015). Samoin se, että osallistujat tuntevat olevansa yhdenvertaisia ja puhuvat samaa kieltä (Joshi 2018). Brink ja Wamsler (2018) suosittelevat kuntia kehittämään yhteistyötä kansalaisten kanssa ilmastonmuutokseen sopeutumisessa. Tämä tapahtuu lisäämällä tietoisuutta kansalaisten mahdollisuuksista ja vastuista sekä kiinnittämällä huomio marginaalisten ja havoittuvien ryhmien osallistamiseen.

"Miten pitäisi ybteiskehittäă" -kysymykseen löytyy enemmän vastauksia kirjallisuudesta kuin "miksi"-kysymykseen. Tiivistäen ohjeena on kunnan hallinnon kehittäminen joustavaksi ja oppivaksi (Brink \& Wamsler 2018; Frantzeskaki 2019; Paloniemi 2019a; Voorberg ym. 2015), saavutettavien hyötyjen näkyväksi tekeminen (Frantzeskaki 2019; Paloniemi 2019a) ja kansalaisten osallistumismahdollisuuksien edistäminen (Frantzeskaki 2019; Puerari ym. 2018; Voorberg ym. 2015).

Kunnallishallinnon kehittämistä joustavaksi ja oppivaksi suositellaan sekä organisaation sisäisesti että ulkoisesti kansalaisten ja muiden sidosryhmien suuntaan. Frantzeskaki (2019) suosittelee kaupunkisuunnittelijoille avoimuutta luontopohjaisten ratkaisujen kehittämisessä ja ylläpidossa. Kaupungin institutionaalisia tiloja tulee muotoilla yhteistyötä mahdollistaviksi 
ja projektien johtajuutta tulee luovuttaa muille toimijoille. Luontopohjaisten ratkaisujen yhteiskehittämiseen tarvitaan uusia luovia menetelmiä ja hallinnon ohjeita tulee suunnitella yhdessä kansalaisyhteiskunnan toimijoiden kanssa. Voorberg ym. (2015) mukaan julkisten palveluiden yhteiskehittämisessä on huomioitava hallintokulttuurin ominaispiirteiden ja julkisten organisaatioiden menettelytapojen yhteensopivuus kansalaisten osallistumisen kanssa. Yhteiskehittämisen tehostamiseksi tarvitaan pitkän aikavälin sitoutumista yli yhden projektin aikajänteen (Franz ym. 2015).

Hyödynnämme tässä tutkimuksessa edellä kuvattua teoreettista taustaa keskittymällä yhdessä oppimisen kysymykseen, joka on yhteiskehittämisen tärkeä (Puerari ym. 2018) tai jopa tärkein saavutus (Prahalad \& Ramaswamyn 2004). Kun teimme tutkimusta osana yhteiskehittämisen prosessia, teoreettinen oletus yhdessä oppimisen merkityksestä vahvistui käytännössä. Eri osallistujaryhmät - asiantuntijat, toteuttajat ja kaupunkilaiset - kaipasivat lisää tietoa sekä kaupunkien ongelmista että mahdollisista luontopohjaisista ratkaisuista. Yhdessä oppimisessa meitä kiinnostaa erityisesti yhteisen vision muodostuminen (Paloniemi 2019a), eri toimijoiden osaamisen yhdistäminen kohti onnistunutta toteutusta (Raymond ym. 2017) ja luovat yhteiskehittämisen menetelmät (Frantzeskaki 2019).

\section{Tutkimuskohteet, aineistot ja menetelmät}

Tampere on Unalab-hankkeessa edelläkävijäkaupunkina yhdessä Eindhovenin (Alankomaat) ja Genovan (Italia) kanssa. Lisäksi hankkeessa on mukana seuraajakaupunkeja, tutkimuslaitoksia ja yrityksiä. Kaikkiaan hankekumppaneita on 28. Hanketta koordinoi Teknologian tutkimuskeskus VTT. Projektin tavoitteena on:

"Yhteiskehittää elävissä laboratorioissa tutkittua tietopohjaa ja eurooppalaista vïitekehystä innovatiivisille, monistettaville, paikallisesti mukautetuille luontopohjaisille ratkaisuille, jotka edistävät kaupunkien ilmasto- ja vesiresilienssiä. Unalabissa edistetään ekologista vesibuoltoa, viherretään kaupunkia sekä osallistetaan sidosryhmiä kaupunkisuunnitteluun.” (Unalab-bankesuunnitelma, käännös kirjoittajien)

Tampereen elävät laboratoriot ovat Vuores ja Hiedanranta. Vuores on luonnontilaiselle alueelle 14 vuotta sitten kaavoitettu kaupunginosa seitsemän kilometrin päässä kaupungin keskustasta. Nyt siellä asuu noin 5000 ihmistä ja suunnitelmissa on rakentaa uusia koteja 14000 asukkaalle vuoteen 2025 mennessä. Vuores-projektin alkumetreillä metsään ja järvien keskelle rakentamista kritisoitiin. Luonnonympäristöön kajoamisen kompensaationa Vuoreksen kestävyystavoitteet asetettiin korkealle. Muun muassa hulevesijärjestelmä suunniteltiin edistykselliseksi harmaata, sinistä ja vihreää infrastruktuuria yhdistäväksi kokonaisuudeksi. Hiedanranta on kaupungin omistama entinen sellutehdasalue neljän kilometrin päässä keskustasta, Näsijärven rannassa. Hiedanrannassa ei ole vielä asukkaita, mutta suunnitelmien mukaan sinne tulee 25000 asukasta seuraavien 30 vuoden kuluessa. Vuonna 2016 alue rakennuksineen muuttui eläväksi laboratorioksi, kun kaupunki avasi sen kaupunkilaisille, yrityksille ja muille toimijoille kaupungin kestävyyttä edistävään kokeilutoimintaan.

Projektissa järjestettiin keväällä 2018 molemmilla kohdealueilla kolmen työpajan sarjat, joiden tavoitteena oli yhteiskehittää projektissa toteutettavia luontopohjaisia ratkaisuja. Työpajat noudattivat palvelumuotoiluajattelua, jossa ensin visioidaan mitä luontopohjaiset ratkaisut kussakin kohteessa voisivat olla ja mitä ongelmia niillä ratkaistaan. Toisessa vaiheessa innovoidaan ratkaisumalleja ja viimeisessä vaiheessa pilotoidaan valittua ratkaisua sen kehittämiseksi. Työpajoihin osallistui 258 ihmistä, joista suurin osa oli asukkaita. Monet työpajoista järjestettiin osana muita aihepiiriin sopivia tapahtumia, kuten seminaareja ja erilaisia yleisötapahtumia. Työpajoissa opittiin yhdessä ja ideoitiin luontopohjaisia ratkaisuja yleisesti. Toteutussuunnitelmat laadittiin työpajojen jälkeen työryhmissä, joihin koottiin kunkin pilotin kannalta tarpeelliset asiantuntijat. Lisäksi järjestimme ajankohtaisista 
Taulukko I. Luontopohjaisten ratkaisujen yhteiskehittämisen prosessi Tampereen kohdealueilla.

Table I. Co-creation of nature-based solutions in Tampere living labs.

\begin{tabular}{|c|c|c|}
\hline & Pilottialue Hiedanranta & Pilottialue Vuores \\
\hline $\begin{array}{l}\text { Viralliset } \\
\text { yhteiskehittämisen } \\
\text { työpajat keväällä } \\
2018\end{array}$ & $\begin{array}{l}\text { Kolme työpajaa: } \\
\text { - Asiantuntijoille osana Avoin asiakkuus } \\
\text { ja osallisuus -seminaaria } \\
\text { - Asiantuntijoille osana } \\
\text { Luontopohjaisten ratkaisuiden } \\
\text { seminaaria } \\
\text { - Lähialueen asukkaille ohjattu } \\
\text { kaupunkikävely kaupunkisuunnittelu- } \\
\text { tapahtuman jälkeen } \\
\text { Työskentely organisoitiin kolmen tee- } \\
\text { man mukaan: vesi, luonnon monimuo- } \\
\text { toisuus ja virkistys. Tavoitteena yhtei- } \\
\text { nen visio, luontopohjaisten ratkaisuiden } \\
\text { ideointi ja pilottikohteiden valinta. }\end{array}$ & $\begin{array}{l}\text { Kolme työpajaa: } \\
\text { - Asukkaille ja asiantuntijoille ilta- } \\
\text { tilaisuus, jossa alustuksia ja luonto- } \\
\text { pohjaisten ratkaisujen muotoilupeli } \\
\text { - Koululaisille alustuksia ja luonto- } \\
\text { pohjaisten ratkaisuiden rakentamista } \\
\text { koulupäivän aikana } \\
\text { - Asukkaille luontoretki ja infoteltta } \\
\text { osana Vuores-päivää } \\
\text { Työskentely organisoitiin alueen } \\
\text { olemassa olevien luontopohjaisten } \\
\text { hulevesiratkaisuiden mukaan. Tavoittee- } \\
\text { na yhteinen visio, kehitystarpeiden ja } \\
\text {-ideoiden kerääminen sekä oppiminen. }\end{array}$ \\
\hline $\begin{array}{l}\text { Asiantuntijoiden } \\
\text { työryhmät pilotti- } \\
\text { en toteutussuun- } \\
\text { nitteluun }\end{array}$ & $\begin{array}{l}\text { Biosuodatin: } \\
\text { - Laaja ryhmä, jossa osaamista hule- } \\
\text { vesien käsittelystä ja kohteesta } \\
\text { Viherkatto: } \\
\text { - Pilotin oma ohjausryhmä, jossa osaa- } \\
\text { mista viherkatoista ja rakennusalasta } \\
\text { - Talonrakennushankkeen suunnittelu- } \\
\text { ryhmä } \\
\text { - Erillinen viherkattotyöpaja asian- } \\
\text { tuntijoille }\end{array}$ & $\begin{array}{l}\text { Hevoshaka: } \\
\text { - Hakijoille sparraustilaisuuksia, } \\
\text { joissa tietoa avustuksesta ja luonto- } \\
\text { pohjaisista ratkaisuista } \\
\text { - Toteutussuunnittelu hevostilan ja } \\
\text { kaupungin kesken neuvotellen }\end{array}$ \\
\hline $\begin{array}{l}\text { Muut } \\
\text { yhteiskehittämisen } \\
\text { tapahtumat }\end{array}$ & $\begin{array}{l}\text { - Pilottikohteiden ja luontopohjaisten } \\
\text { ratkaisuiden esittelyjä vierailija- } \\
\text { ryhmille } \\
\text { - Urban living lab -koulutus Hiedan- } \\
\text { rannan toimijoille } \\
\text { - Kaupunkisuunnittelijoiden opinto- } \\
\text { matkat, joilla on tutustuttu mui- } \\
\text { den kaupunkien luontopohjaisiin } \\
\text { ratkaisuihin }\end{array}$ & $\begin{array}{l}\text { - Verkkokysely Vuoreksen luonto- } \\
\text { pohjaisista ratkaisuista } \\
\text { - Koululaisille maasto-opetusta veden- } \\
\text { laadun ja luonnon monimuotoisuuden } \\
\text { mittauksesta } \\
\text { - Viljelylaatikoiden ja linnunpönttöjen } \\
\text { nikkarointityöpaja } \\
\text { - Luontopolun avajaiset } \\
\text { - Pilottikohteiden ja luontopohjaisten } \\
\text { ratkaisuiden esittelyjä vierailija- } \\
\text { ryhmille }\end{array}$ \\
\hline
\end{tabular}

aiheista useita pieniä tilaisuuksia, jotka ajattelemme olevan osa yhteiskehittämistä. Yhteiskehittämisen prosessi on kuvattu taulukossa 1.

Alkuperäisten hulevesipainotteisten projektisuunnitelmien ja monivaiheisen yhteiskehittämisen ohjaamana kohdealueille suunniteltiin muun muassa tässä tutkimuksessa tarkasteltavat luontopohjaiset ratkaisut: biosuodatin, hevoshaka ja viherkatto. Näistä biosuodatin ja hevoshaka on jo toteutettu. Viherkaton toteutus ei ole toistaiseksi onnistunut pilottialueille eikä muuallekaan Tampereella. Sille etsitään edelleen sopivaa kohdetta.

Tampereen osaprojektia koordinoi kaupunki ja työtä tukevat Teknologian tutkimuskeskus VTT'T sekä konsulttiyritys Ramboll. Tutkimus on tehty projektin sisältä käsin ja me kirjoittajat olemme kaksoisroolissa projektin vetäjinä ja tutkijoina. Työhömme kuuluu Tampereella toteutettavien luontopohjaisten ratkaisujen yhteiskehittämisen koordinointi sekä ympäristöalan asiantuntijatehtävät. Tutkijan roolissa tarkastelemme projektin etenemistä kriittisesti, mikä vaikuttaa myös projektityöhömme. Voimme esimerkiksi muokata projektisuunnitelmia 
tutkimustulosten perusteella. Toisaalta taas projektityömme vaikuttaa tutkimukseen. Sisältä päin näemme yhdessä oppimisen prosessin tarkasti. Riskinä taas ovat yksipuoliset oletukset ja tulkinnat (Bonner \& Tolhurst 2002). Coghlanin (2007) mukaan tutkijoiden pitäisi olla tarkkaavaisia, järkeviä ja vastuullisia tehdessään tutkimusta prosessin sisältä päin.

Kehitämme tässä tutkimuksessa eräänlaista institutionaalista etnografiaa (Smith 2002) käymällä yhteiskehittämisen dialogia osallistujien kanssa. Instituutiot vaikuttavat tietämisen ja yhdessä oppimisen edellytyksiin, ja niiden vaikutus voi olla näkyvää tai tiedostamatonta (Tuomisaari \& Peltola 2011). Analyysissä peilaamme osallistujien kokemuksia ja näkemyksiä asuinalueista laajempiin infrakehitystä ohjaaviin instituutioihin, joita ovat ammattiosaaminen, kaupunkisuunnittelu ja EU-projekti. Tutkimusasetelmassamme kaikki osallistujat oppivat yhdessä, myös projektin vetäjät, ja tutkimusasenteeseen kuuluu itsekritiikki. Metodologian kehittelyssä olemme saaneet vaikutteita prosessin sisäpuolella tapahtuvasta toimintatutkimuksesta. Toimintatutkimuksen tapaan meille on kertynyt osaamista organisaatiosta ja kehitettävästä prosessista (Coghlan 2007). Kuten Bonner ja Tolhurst (2002) esittävät hoitotyötä käsittelevässä tutkimuksessaan, mekin loimme yhteiskehittämisen vetäjinä luottamuksellisia suhteita osallistujiin ja olimme paikalla aina kun tapahtui, mikä auttoi rikkaan aineiston keräämisessä. Projektin sisällä tutkijan haasteena on kaksoisrooli, jossa tutkimus toisaalta vaatii tiivistä osallistumista kehitystyöhön, ja toisaalta etäisyyttä, jotta voi tarkastella toimintaa kriittisesti (Coghlan 2007).

Tutkimusaineiston muodostavat: 1) Työpajojen vetäjien laatimat tulosraportit, joissa kuvataan työpajojen tavoitteita, työskentelytapoja ja tuloksia. 2) Koko EU-projektin konsortion ja työpakettien kokousmuistiot, joissa kuvataan projektin organisoitumista ja yhteiskehittämisen ohjausta ylhäältä päin. 3) Tampereen osaprojektin ja kohteiden suunnittelukokousten dokumentit, joissa kuvataan pilottien yhteiskehittämisen vaiheita ja käytännön toteutusta. 4) Omat havaintomme ja muistiinpanomme monivaiheisesta yhteiskehittämisestä ja yhteydenpidosta sidosryhmiin. Havaintoaineisto sisältää dokumenttien ulkopuolelle jääviä tapahtumia ja kommunikointia, joilla täydennämme tapahtumakuvausta yhteiskehittämisestä ja yhdessä oppimisesta. Lisäksi havaintoaineisto sisältää tarkennuksia - eri toimijoiden rooleja ja oppimistilanteita - kirjalliseen aineistoon. Peilaamalla aineistoja toisiinsa muodostamme tarkan kuvauksen yhdessä oppimisen tilanteista yhteiskehittämisen prosessissa.

Aineiston analyysimenetelmä on laadullinen sisällönanalyysi (Tuomi \& Sarajärvi 2018) ja analyysiyksikkönä ovat yhteisen oppimisen tilanteet. Kirjallisuuden ohjaamana kiinnitimme huomiota erityisesti yhteisen vision muodostumiseen (Paloniemi 2019a), eri toimijoiden osaamisen yhdistämiseen kohti onnistunutta toteutusta (Raymond ym. 2017) ja luoviin yhteiskehittämisen menetelmiin (Frantzeskaki 2019). Yhteisen vision muodostuminen ilmeni aineistossa siinä, miten luontopohjaiset ratkaisut yhdistivät toimijoita yhtäältä positiivisesti ja toisaalta toivat esiin intressiristiriitoja. Osaamisen yhdistäminen käytännön toteutuksessa näkyi aineistossa toistuvana tarpeena vastata yhteistyön avulla luontopohjaisten ratkaisujen monimutkaisuuteen. Luoviksi menetelmiksi tulkitsimme oppimistapahtumia, jotka poikkesivat perinteisestä osallistamisesta kaupunkisuunnittelussa. Lisäksi hahmottelimme aineistosta kaksi uutta teemaa. Vastavuoroinen oppiminen ilmeni, kun tarkastelimme tapahtumia, jotka yhdistivät eri toimijoiden rooleja, kohtaamisia ja niiden vaikutuksia. Halu oppia ilmeni eri osapuolille järjestettyjen koulutustapahtumien suosiossa ja niistä saadussa palautteessa. Seuraavissa luvuissa esittelemme näitä yhdessä oppimisen tilanteita osana kolmen pilottikohteen yhteiskehittämisen prosessia.

\section{Yhteiskehittämisen työpajojen anti}

Koko EU-hankkeen konsortio odotti, ylhäältä päin, että Tampereen työpajoissa konkreettisesti muotoiltaisiin projektissa toteutettavat luontopohjaiset ratkaisut. 
Käytännössä emme edenneet virallisissa työpajoissa yksittäisten ratkaisujen muotoiluun vaan ideoimme laajasti luontopohjaisten ratkaisujen mahdollisuuksia kohdealueilla.

\section{Osallistujien ideointi}

Työpajatulokset on jaoteltu seuraavien kolmen teeman alle: vesi, virkistyskäyttö ja luonnon monimuotoisuus. Työpajoissa Vuoreksen suunnitelmiin saatiin osallistujilta seuraavaa evästystä: 1) Hulevesien hallintaan liittyen toivottiin tehokasta suodatusta erityisesti ennen herkkää Särkijärveä. Puhdistamiseen ideoitiin kelluvia kasvilauttoja, biosuodattimia ja kalkkisuodatinta. Lisäksi toivottiin lisää tietoa alueen hulevesijärjestelmästä. 2) Osallistujat toivoivat myös virkistysmahdollisuuksien kehittämistä ja aktiivisen toiminnan alueita, kuten polkuja, pitkospuita, lintutorneja, kaupunkiviljelymahdollisuuksia, uimarantoja, kuntoilulaitteita, kiipeilyseiniä, frisbeegolfrataa, ratsastusreittejä ja nuotiopaikkaa sekä parkkialueita reittien läheisyyteen. 3) Osallistujat olivat kiinnostuneita myös luonnon monimuotoisuudesta ja toivoivat hyönteishotelleja, lepakon- ja linnunpönttöjä sekä viljelylaareja. Kasvillisuuden niiton ja lupiinien kitkemisen alueen niityiltä arvioitiin olevan tarpeen. Yleisesti toivottiin villimpiä puistoja ja sitä, ettei puita enää kaadettaisi. Tervaslammenpuiston kohdalla toivottiin lahopuiden jättämistä paikoilleen. Lisäksi toivottiin lisää tietoa alueen luontoarvoista.

Hiedanrannassa ei ole vielä asukkaita, joten työpajoja kohdennettiin enemmän asiantuntijoille, mikä näkyy tuloksissa kaupunkisuunnittelun termien hallinnassa ja Vuoresta yleisemmissä tavoitteissa. Tulosraportin mukaan erimerkiksi "Kiinteistöjen pihat tulee saattaa osaksi sini-vibreää verkekoa monimuotoisen kasvillisunden ja persoonallisten bulevesiratkaisujen kautta." Hiedanrannassa kolme teemaa saivat seuraavan sisällön. 1) Hulevesiin liittyviä ideoita olivat alueen veden laadun (sellutehtaan vanhat päästöt) parantaminen, viherpainanteet ja virtaava vesi. Hulevesialtaat nähtiin monimuotoisen luonnon ja monipuolisen toiminnan kasvualustoiksi. 2) Virkistysnäkökulmasta nousi esiin Näsijärven rannan hyödyntäminen niin, että järvinäköala on kaikkien saavutettavissa. Virkistyskäyttömahdollisuuksia toivottiin parannettavan ja samalla luonnon rauhaa säilytettävän. Alueelle suuntautuvasta kovasta rakentamispaineesta huolimatta toivottiin rakentamattomia alueita, vapaan tekemisen viherkenttiä ja yleisötapahtumien paikkoja, palsta- ja laatikkoviljelyä, kasvihuoneita ja erilaisten toimintojen limittämistä. 3) Luonnon monimuotoisuutta painottaen toivottiin monipuolista puustoa, sammalkattoja, lahopuuta ja rantaniittyjä. Lisäksi pidettiin tärkeänä hoidetun puiston ja villimmän luonnon tasapainoista vuorottelua sekä teollisen perinnön jättämistä näkyväksi. Esimerkiksi teollisuuden mukana alueelle kulkeutuneita ruderaattilajeja (joutomailla viihtyviä kasveja) voitaisiin vaalia alueen viherrakentamisessa ja vanhojen teollisuusrakennusten toivottiin säilyvän. Vieraslajien torjuntaan pitäisi kiinnittää huomiota ja jäljellä olevan metsän toivottiin säilyvän.

\section{Miten tuloksia hyödynnettiin}

Projektissa toteutettaviksi kaavaillut luontopohjaiset järjestelmät olivat alun perin hulevesipainotteisia, mutta suunnitelmia päivitettiin työpajatulosten perusteella lisäämällä biosuodatin Hiedanrannan sellukaatopaikan suotovesille. Vuoreksen suunnitelmia täydennettiin luontopolulla pitkospuineen sekä alueen luontoarvoista ja hulevesiratkaisuista kertovilla infotauluilla. Yleisön pyynnöstä järjestettiin myös linnunpönttöjen ja viljelylaarien nikkarointityöpaja Vuoreksen koululla. Lisäksi sidosryhmien esiin tuomia näkemyksiä on huomioitu suunnittelussa. Näitä ovat esimerkiksi Hiedanrannan identiteettiä korostava järven virkistyskäyttö ja teollisen perinnön vaaliminen. Vuoreksessa korostunut lähiluonnossa liikkuminen on huomioitu pilottien toteutussuunnittelussa.

Hiedanrannassa ja Vuoreksessa on käynnissä aktiivinen aluesuunnittelu ja rakentamisen aiheuttama muutos. Monet työpajoissa esitetyistä näkemyksistä kohdistuivat 
kaupunkisuunnitteluun projektitasoa laajemmin, mutta viestiä saatiin kuitenkin eteenpäin, koska kaupungin viher- ja hulevesisuunnittelijat osallistuivat työpajoihin. Suunnittelijoiden oli helppo tarttua nopeasti toteutettaviin ja rutiininomaisisiin pyyntöihin, jotka koskivat esimerkiksi väylien kunnossapitoa. Samoin projektiin vain löyhästi liittyviin ehdotuksiin pystyimme vastaamaan laajentamalla luontopohjaisten ratkaisujen kehystä niin, että esimerkiksi pitkospuut ja hevoshaka mahtuivat sen sisään. Sen sijaan työpajoissa esiin nousseet laajemmat kysymykset, kuten metsien ja vanhojen teollisuusrakennusten säästäminen jäivät avoimiksi. Myös muiden kaupungin yksikköjen toimivaltaan liittyvät ehdotukset, esimerkiksi uimaranta, päätyivät toiveiden tynnyriin, jonka käsittelystä ei ole tietoa. Jotta yhteiskehittäminen olisi mielekästä, olisi tärkeä asettaa tavoitteet selkeästi ja sopia tulosten käsittelystä ja käytöstä läpinäkyvästi. Yksittäisen projektin hankaluutena on saada se yhdistymään pitkän aikavälin kaupunkikehitykseen.

\section{Yhdessä oppiminen}

Ensisijaisesti työpajat mahdollistivat yhdessä oppimista, mikä on tyypillisesti yhteiskehittämisen keskeinen saavutus (Puerari ym. 2018). Luontopohjainen ratkaisu on uusi käsite, jonka tuntevat vain ympäristöalan ammattilaiset. Lisäksi luontopohjaisten ratkaisujen merkitys Suomessa on epäselvä, kun luonto on kaupungeissakin lähellä ja ilmastonmuutoksen vaikutukset etäisiä. Koska aihe oli uusi ja ongelmat etäisiä, yhdessä oppimisesta eri muodoissaan - työpajat alustuksineen, projektin aikana laadittu luontopohjaisten ratkaisujen käsikirja, luokka- ja maasto-opetus koululaisille, seminaarit, opintomatkat kaupungin edustajille, nikkarointityöpaja, infotaulut maastossa, kaupunkikävely ja karttapohjainen verkkokysely - muodostui pilottiprojektin keskeinen ja arvostettu osa. Emme osanneet asettaa oppimista etukäteen yhteiskehittämisen keskeiseksi tavoitteeksi vaan sen merkitys kirkastui prosessin edetessä, kun eri toimijat pyysivät koulutusta luontopohjaisista ratkaisuista. Projektin puitteissa meillä oli myös resursseja reagoida näihin pyyntöihin. Osaamisen puute on usein esteenä totuttujen toimintatapojen muuttamiselle (Paloniemi 2019a) ja onkin rohkaisevaa huomata, että tiedolle on kysyntää.

Sidosryhmät toivat keskusteluun monenlaista osaamista ja tavoitteita. Asukasaktiivien kommenteissa korostuivat paikallistuntemus ja asukkaiden edunvalvonta. He toivoivat alueen virkistysmahdollisuuksien kehittämistä ja ratkaisuja alueen ongelmiin, kuten puuttuviin kulkureitteihin tai asukkaille tärkeän metsän kaatamiseen asutuksen levitessä. Luonnontilaisen ympäristön säilyttäminen on tärkeä näkökohta, jota asukkaat toivat esille. Se puuttui projektin kaupunkivetoisista suunnitelmista, joissa luontopohjaisten ratkaisujen tulkinta oli tekninen. Esimerkiksi Vuoreksessa metsää kaadetaan asutuksen alta ja suolle muokataan teknisiä, joskin luontopohjaisia, ratkaisuja hulevesien hallintaan. Infrarakentajien kokemusten mukaan suoalueille rakentaminen on tullut kalliiksi ja heikosta kantavuudesta on aiheutunut rakennusteknisiä hankaluuksia. Infrarakentamisen edellyttämistä suoalueiden massanvaihdoista aiheutunut kuormitus alapuolisiin vesiin on ollut voimakasta. Näyttääkin siltä, että suoalueiden säilyttäminen rakennettavien alueiden välissä luontaisina tulvia tasaavina ja vesiä puhdistavina ratkaisuina olisi hyödyllisempää kuin keinotekoisten, vaikkakin luontopohjaisten järjestelmien rakentaminen niiden tilalle. Luonnontilaisen ympäristön suojelun pilottikohde olisi ollut yhteiskehittämisen hengen mukainen, mutta sellaista emme toteuttaneet.

Luontojärjestön edustajilta saimme asiantuntevia näkemyksiä luonnon monimuotoisuuteen. He haastoivat kaupungin perinteisiä suunnitteluratkaisuja sekä hierarkkista kaupunkisuunnittelun ja -toteutuksen tapaa. Luontojärjestön edustajat toivoivat nykyistä monimuotoisempaa ympäristöä, jossa olisi tilaa luonnolle ja ihmisten aktiiviselle toiminnalle. He myös tarjosivat esimerkkejä siitä, miten luontopohjaisten ratkaisujen vetovastuuta voidaan siirtää kaupungilta muille toimijoille. Tällaisia keinoja ovat esimerkiksi osallistava budjetointi sekä niittyjen perustaminen ja ylläpito talkoilla. Työpajoihin kutsuttiin 
osallistujia useista luontojärjestöistä, mutta vain yhden kaupunkiluontoon erikoistuneen järjestön edustajat osallistuivat. Vähäinen osallistuminen voi johtua resurssien puutteesta tai siitä, etteivät perinteiset luontojärjestöt koe luontopohjaisten ratkaisujen kuuluvan omalle toiminta-alueelleen.

Kaupungin ja konsultin edustajat innostuivat projektista ja osallistuivat yhteiskehittämiseen avoimesti. Ohjasimme esimerkiksi koululaisten työpajoja, keskustelimme asukkaiden kanssa kävelyillä ja autoimme hevostilaa hevoshaan kehittämisessä. Kohteissa henkilökohtaisesti kuultu palaute jäi meille asiantuntijoille vahvasti mieleen ja sitoutti meitä seuraamaan, että ideat kantoivat suunnitelmiin asti. Muokkasimme myös jäykäksi kokemaamme yhteiskehittämisen prosessia paremmin paikallisiin tarpeisiin vastaavaksi niin, että suuntasimme työpajat valikoidusti eri kohderyhmille (Taulukko 1). Kokemustemme mukaan asukkaiden kanssa yhdessä ideoidut tilaisuudet ovat tavoitteeltaan selkeitä ja he osallistuvat niihin aktiivisesti. Sen sijaan ylhäältä alaspäin ideoidut tilaisuudet jäävät helposti pinnallisiksi eivätkä asukkaat koe niihin osallistumista tarpeelliseksi.

EU-projektin yhteensovittaminen elävään kaupunkiin aiheutti kitkaa. Lähes kaikki projektikumppaneiden työ muissa maissa tähtäsi tavalla tai toisella luontopohjaisten ratkaisujen yhteiskehittämiseen edelläkävijäkaupungeissa. Esimerkiksi yhteiskehittämisen työkaluja kehittivät useat kumppanit. Kokeilulla oli myös paikallisia reunaehtoja; esimerkiksi luontopohjaisten ratkaisujen toteutuksessa noudatimme kaupungin hankintamenettelyä. Projektikonsortion ohjaaman työpaketin vaatimus järjestää työpajat ennen ratkaisujen toteutusta sekä nopeaan investoimiseen kannustava rahoitusmalli aiheuttivat aikataulupaineita. Aito yhteiskehittäminen olisi vaatinut enemmän aikaa ja sitä olisi ollut hyödyllistä jatkaa kokeiluiden koko elinkaaren ajan.

\section{Biosuodatin}

Syksyllä 2018 rakennettiin Hiedanrantaan biosuodatin, jolla puhdistetaan vanhan sellutehtaan kaatopaikan väkeviä suotovesiä. Kaatopaikkavedet ohjataan muun muassa biohiiltä, turvetta ja kevytsoraa sisältävän noin $100 \mathrm{~m}^{2}:$ n laajuisen ja kolme metriä paksun suodatusalueen läpi. Suodattimen päälle istutettiin syväjuurisia ja alueella alkuperäisenä esiintyviä pensaita ja perennoja pidättämään vettä ja ravinteita. Kaatopaikkavesistä aiheutuvien hajujen poistoon asennettiin aktiivihiilisuodatin kaivon kanteen. Biosuodatin maksoi 68600 euroa. Kuvassa 1 on biosuodatin pian valmistumisen jälkeen. Taustalla nouseva mäki on maisemoitu sellukaatopaikka. Suotovedet johdetaan suodattimeen oikealta, missä näkyy mittauskaivo. Istutusten lomassa on tuuletusputkia ja kuvaajan takana Näsijärvi, jonne puhdistetut vedet puretaan.

Biosuodatin ei ollut mukana alkuperäisessä projektisuunnitelmassa vaan sai alkunsa projektin aikana. Aloitteen syntymiseen vaikuttivat kaupungin tavoite kehittää hulevesien laadullista hallintaa, alueen käyttäjien kokemukset hajuhaitoista ja Hiedanrannassa sijaitsevan biohiilitehtaan intressi edistää biohiilen käyttöä hulevesien hallinnassa. Yhdessä Hiedanrannan yhteiskehittämisen työpajoista, siihen liitetyllä kävelykierroksella, käytiin yhdessä tutustumassa pilottikohteeseen sellukaatopaikan ja Näsijärven reunaa seuraavan pyörätien välissä. Osallistujat pitivät kohdetta hyvänä näköalapaikkana järvelle ja kiittivät ajatusta veden puhdistuksesta järven suojelemiseksi ja hajujen hallitsemiseksi. Tuki idealle biosuodattimesta sekä virkistyskäytön näkökulma tulivat siis kaupunkilaisilta.

Työpajojen jälkeen toteutusta tulivat suunnittelemaan asiantuntijat, joita kutsuttiin mukaan laajalla otannalla aiheen ja kohteen ympäriltä. Suunnitteluun osallistui yhteiskehittämisen periaatteella useita yksiköitä Tampereen kaupungilta: kiinteistötoimi maanomistajan intressin edustajana, viheralueet ja hulevedet -yksikkö hulevesijärjestelmien suunnittelun asiantuntijana ja Hiedanrannan kehitysohjelma aluekehityksen koordinoijana. Mukana oli konsultti vastaamassa suunnitelmien käytännön toteutuksesta ja rakennuttamisesta sekä EU-projektia koordinoiva Teknologian tutkimuskeskus VTT. Lisäksi Hiedanrannan 


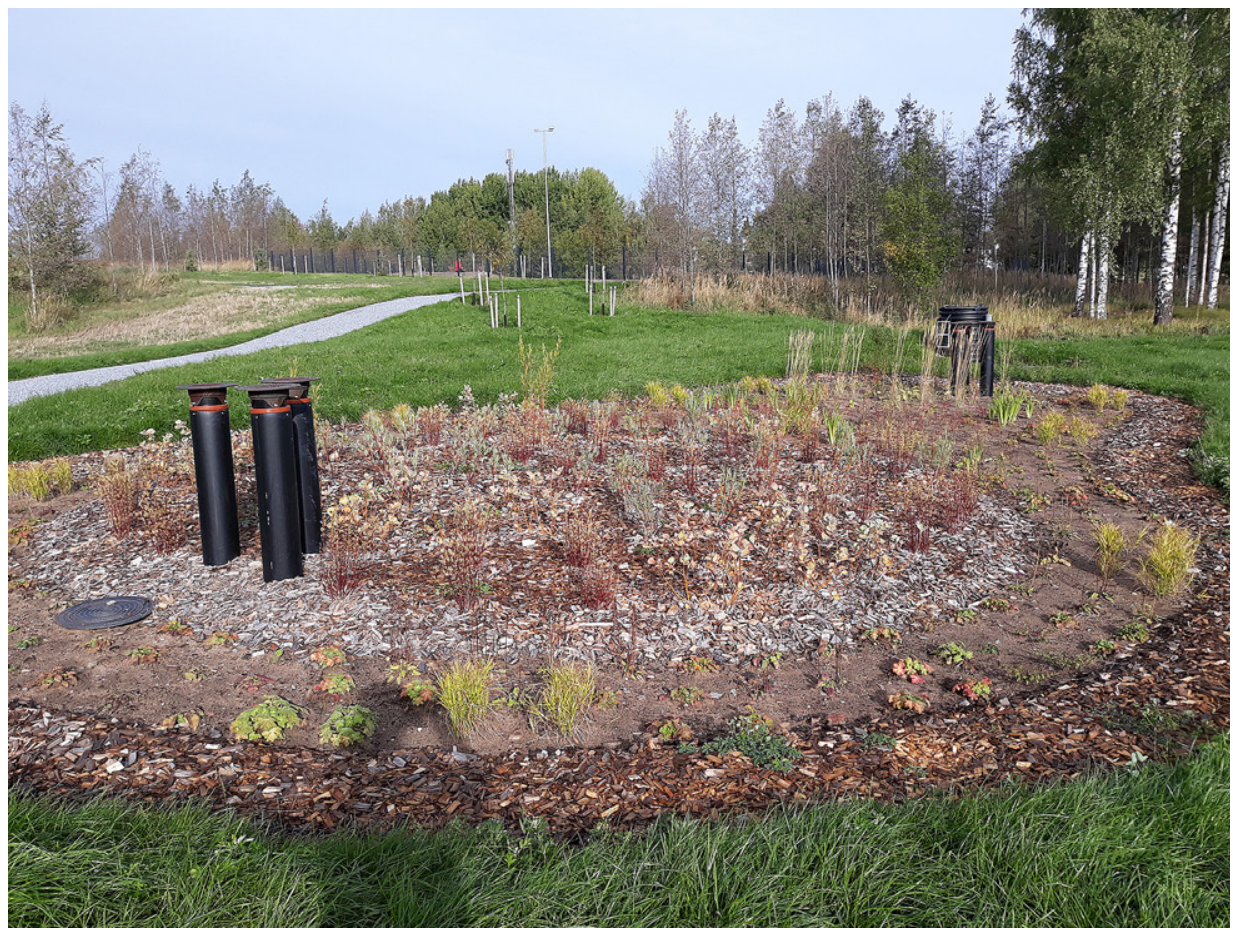

Kuva I. Biosuodatin Hiedanrannan vanhan sellutehtaan kaatopaikan suotovesien käsittelyyn.

Picture I. Biofilter for treatment of seepage waters from industrial landfill.

tekninen isännöitsijä ja biohiilitehtaan edustajat toivat suunnitteluun aluetuntemusta ja biohiiliosaamista. Mukana oli myös elinkeino-, liikenne- ja ympäristökeskus (ELY), jonka päätöksellä sellukaatopaikka on aikanaan suljettu. Mukaan olisi tarvittu vielä lisää visuaalista osaamista, koska suodattimen tuuletusputket eivät kaunista maisemaa (Kuva 1). Myös aiemmissa tutkimuksissa on todettu visuaalinen osaaminen tarpeelliseksi luontopohjaisten ratkaisujen suunnittelussa (Frantzeskaki 2019).

Kapeasti rajatun pilotin ympärille muodostui yhteinen visio, joskin joitakin näkemyseroja havaittiin. Biosuodatin toi olennaisen parannuksen lähtötilanteeseen, jossa kaatopaikan suotovedet johdettiin käsittelemättä järveen. Kuitenkin vain puolen kaatopaikan suotovedet käsitellään biosuodattimessa, minkä vuoksi ELY-keskus nosti esiin tarpeen loppujen suotovesien viemäröinnille. Biohiilivalmistaja olisi halunnut käyttää rautakäsiteltyä biohiiltä parhaan puhdistustuloksen ja referenssikohteen saavuttamiseksi, kun taas suunnittelukonsultti arvioi perusbiohiilen riittävän osana muuta rakennetta. Nämä ovat esimerkkejä Nesshöverin ym. (2017) esiin tuomista luontopohjaisiin ratkaisuihin liittyvistä ristiriitaisista näkemyksistä, jotka vaikeuttavat monimutkaisten ympäristöongelmien ratkomista useiden toimijoiden yhteistyönä. Luontopohjaiset ratkaisut tarjoavat yhdistävää suuntaa, mutta yhteistyön pitää olla huolellisesti ohjattua.

Biosuodatin vaikutti aluksi toimivan tehokkaasti veden puhdistuksessa, mutta pian havaittiin kapasiteetin riittämättömyys. Seuranta osoitti, että puhdistusteho heikkeni ja ravinteita alkoi huuhtoutua rakenteesta järveen sulamisvesien mukana. Vesiä on jouduttu ohjaamaan suodattimen ohi ojaan ylivuotona helmikuusta 2019 alkaen. Vaikuttaa siltä, että yläpuoliselta valuma-alueelta ohjautuu katuvesiä suodattimelle enemmän kuin alueen hulevesiverkoston piirustusten ja aiempien virtausmittausten perusteella arvioitiin. Näin ollen edessä on korjaus, jossa katuvedet ohjataan suodattimen ohi läheiseen hulevesialtaaseen. Vesien ohjauksen jälkeen suodatin huuhdellaan ja tarvittaessa kuvataan. 
Jos korjaustoimet eivät tehoa, täytyy rakennetta avata ja katsoa, onko suodatin esimerkiksi tukossa. Mitoitusongelma kuvaa hyvin luontopohjaisten ratkaisujen monimutkaisuutta.

Suodattimen tulvimisen lisäksi uusi ratkaisu toi mukanaan muitakin yllättäviä käytännön käänteitä ja odottamattomia kustannuksia. Kaatopaikan reunaan rakennettaessa kaivuutöiden yhteydessä tuli vastaan autonrenkaita ja pilaantunutta maata, jonka käsittelyyn haettiin ELY-keskuksen lausunto. Renkaat ja pilaantunut maa kuljetettiin ohjeiden mukaisesti kaatopaikalle. Työmaalla ja mittauskaivoissa havaittiin kaatopaikkakaasuja ja alhainen happipitoisuus, mikä johti terveystarkastuksiin ja suojavarusteiden käyttöön sekä rakennustyömaalla että mittauspisteitä huollettaessa. Pohjan eristematon asennus epäonnistui ensimmäisellä kerralla ja se uusittiin. Vanhalta kaatopaikalta suotautui työmaan kuoppiin vettä, jonka pumppaus hidasti töitä. Hankkeeseen osallistujat joutuivat sopeutumaan eteen tuleviin tilanteisiin ja oppivat matkan varrella paljon muun muassa mitoituksesta, rakentamisesta, mittauksesta ja työturvallisuudesta. Kaupungin hallinnossa biosuodatin lisäsi tietoisuutta luontopohjaisista ratkaisuista ja keskustelua eri yksiköiden välillä.

Biosuodatin on hyvä esimerkki monimutkaisesta luontopohjaisesta ratkaisusta, jonka onnistuminen vaatii Nesshöverin ym. (2017) mukaan epävarmuuksien ja monimutkaisuuden huomioonottamista, kattavaa sidosryhmien osallistamista, monialaisen osaamisen hyödyntämistä ja yhteisen näkemyksen muodostamista. Näiden lisäksi tarvitaan arviointia ja seurantaa, jotka ovat tärkeitä myös oppimiselle. Monet edellä luetelluista asioista toteutuivatkin biosuodattimen toteutuksen yhteydessä. Esimerkiksi eri alojen asiantuntijoista koostuva suunnittelijaryhmä auttoi monimutkaisuuden hallinnassa ja vedenlaadun seuranta toi esiin mitoitusongelmat, joita ei välttämättä muuten olisi havaittu. Vaikka kohde suunniteltiin huolellisesti, yllätyksiä ja korjattavaa tuli eteen monessa vaiheessa. Prosessia olisi voinut parannella nostamalla yhdessä oppiminen selvemmin yhteiskehittämisen tavoitteeksi (Prahalad \& Ramaswamyn 2004), mikä olisi luonut tilaa monimutkaisuuden hyväksymiselle ja hallinnalle (Nesshöver ym. 2017). Kokemuksemme tukevat arvioinnin ja seurannan tärkeyttä. Seurannalla havaitaan ratkaisujen ongelmakohtia, joiden korjaamiseen on syytä varautua. Korjauskierrokset ovat tavanomaisia uutuuksien kokeiluissa, mutta vaikeasti hallittavissa luontopohjaisissa ratkaisuissa ne vielä korostuvat.

Yhteiskehittämisen syvällisempi ymmärrys olisi voinut sujuvoittaa biosuodattimen toteutusta ja parantaa sen laatua. Esimerkki kipuilustamme yhteiskehittämisen työkalujen kanssa on testaaminen, joka jäi työpajoissa pinnalliseksi. Ajattelimme, että viimeisessä työpajassa pitäisi olla luontopohjainen ratkaisu testattavana, mutta projektin aikataulu ei sallinut sitä. Työpaketin kokouksessa ehdotettiin myös prototyypin testaamista varsinaisen ratkaisun sijaan, mutta Hiedanrannassa sellaisen rakentaminen monimutkaisesta luontopohjaisesta ratkaisusta hylättiin liian vaikeana. Jälkikäteen tarkasteltuna näkemyksemme prototyypistä oli ehkä liian tekninen, emmekä ymmärtäneet tai rohkaistuneet käyttämään palvelumuotoilun monipuolisia menetelmiä testaamiseen. Olisimme voineet välttää osan kohdatuista vaikeuksista, jos olisimme esimerkiksi toteuttajien, käyttäjien ja ylläpidon kanssa käyneet läpi biosuodattimen palvelupolun piirustusten $\mathrm{ja}$ visualisointien avulla.

\section{Hevoshaka}

Hevoshaka on Vuoreksen kupeessa sijaitsevan hevostilan projekti, joka sai kaupungilta 16400 euron innovaatiosetelin pienimuotoiseen luontopohjaiseen ratkaisuun. Hevostila rakensi hevoshaan Vuoreksen Keskuspuistoon heinäkuussa 2019 ja järjestää siellä hörinähetkiä, joissa hevoset tuodaan tapaamaan kaupunkilaisia (Kuva 2).

Innovaatiosetelillä haluttiin rohkaista muita toimijoita kuin kaupunkia innovoimaan lisää luontoa kaupunkiin. Innovaatiosetelihaun tavoitteita olivat yhteisöllisyys, hulevesien hallinta ja luonnon monimuotoisuus. Hakemuksia tuli kolme ja ne kohdistuivat kahden 


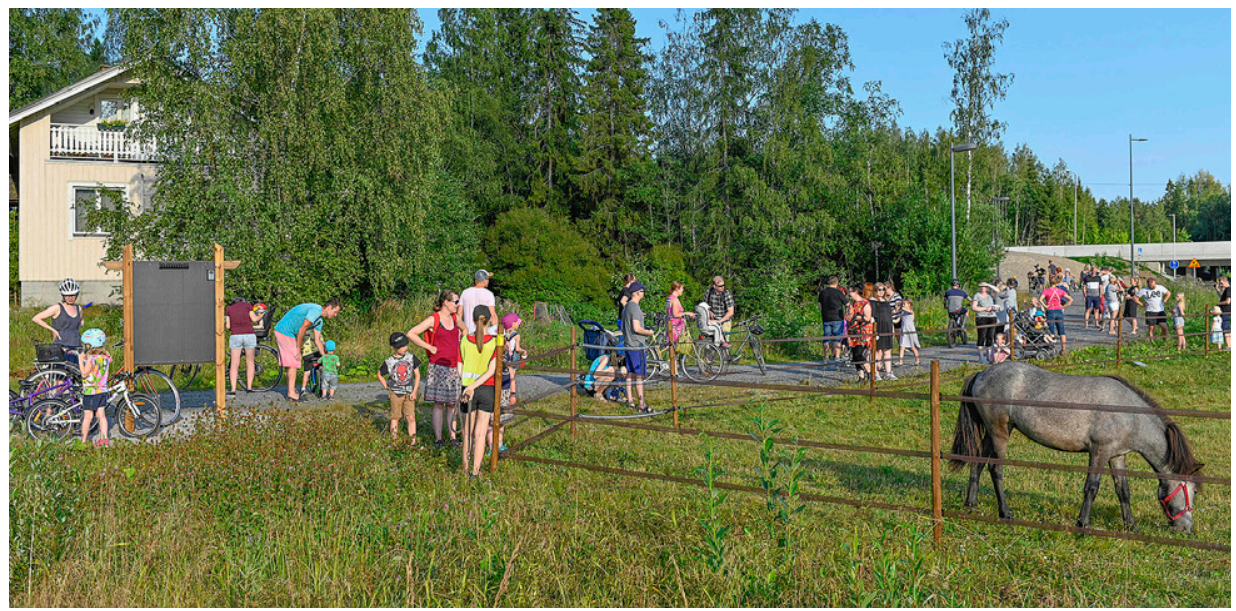

Kuva 2.Vuoreksen Keskuspuiston hevoshaka (kuvaaja Juha Suonpää).

Picture 2. Horses in Vuores Central Park.

taloyhtiön yhteisen pihan kunnostukseen, taloyhtiön pihan istutuksiin ja muovinkeräykseen sekä hevoshakaan. Unalabin Tampereen ohjausryhmä päätti myöntää avustusta muihin haettuihin toimiin paitsi muovinkeräykseen, joka ei sisälly projektin teemoihin. Pihakohteet vastasivat haun tavoitteisiin ja olivat odotettuja. Hevoshaka oli yllättävämpi, mutta toisaalta innovatiivinen avaus luonnosta kaupungissa ja yhteisöllisyydestä.

Hevoshaan taustalla on hevostilan halu kehittää toimintaansa osana Vuoresta ja perustella paikkansa urbanisoituvalla alueella. Hakemuksessa oli mukana myös kritiikkiä Vuoreksen ekologisesta ja sosiaalisesta kestävyydestä sekä halu kehittää näitä:

"Vuoreksen markekinoinnissa käytetty metafora "pikkeukaupunki luonnon kainalossa" luo lupauksen luonnonläheisestä asumisesta, joka toteutun asuinkortteleita ympäröivän metsäluonnon avulla. Vaikka luonto ympäröi kaupunkikortteleita, ei luonto monimuotoisundessaan ole välttämättä vielä osa kaupunkiympäristöä. Esimerkiksi luonnonelänten havainnointi voi jäädä etäiseksi, jos lajien tuntemus on heikekoa. Tarvitaan luontoa, joka on lähellä ibmistä ja osa asuinalueen arkea. Tarvitaan uusia ideoita ja toimintatapojen kehittämistä, mikë tukee paikallisen luontosubteen rakentumista ympäristön kannalta kestävällä tavalla, ybteisöllinen ympäristövastuu ja ilo buomioiden." (Hevostilan innovaatiosetelihakemus)

Hevoshaka poikkeaa kaupungin normeista, koska siinä tuodaan hevosia puistoon. Hevostilan kanssa käytiinkin keskusteluja jo innovaatiosetelin hakuvaiheessa yhteisen näkemyksen saavuttamiseksi ja reunaehtojen huomioimiseksi. Tila oli aktiivisesti yhteydessä kaupunkiin ja pyrki varmistamaan, että hakemus vastaa tavoitteisiin. Kokosimme kaupungilta vastuuhenkilöitä ja neuvottelimme haan sijainnista, hevosten kulkemisesta puistossa ja tarvittavista luvista. Hevostila haki tukea myös hevoshaan naapureissa sijaitsevien koulun ja omakotitalon ihmisiltä. Tiiviillä kommunikoinnilla ja tapaamisilla onnistuttiin rakentamaan luottamusta kaupungin ja hevostilan välille.

Yhteisymmärrykseen päästiin ja alueen vanha tila pääsi toteuttamaan projektia, jossa "Tilan hevoset mahdollistavat unden ja vanhan kohtaamisen sekä tarjoavat väylän kohdata eläimiä vuoreslaisten oman asuinalueen sisällä - börinää kaupungissa." (Hevostilan Facebook-sivu). Hörinähetkissä ei järjestetä tavallista ponitalutusta, vaan hevostilalla toimiva talliryhmä esittelee hevosia ja ihmiset katselevat ja koskettelevat hevosia sekä esimerkiksi kävelevät puistossa talliryhmäläisten taluttamien hevosten kanssa. Tavoitteena on mahdollistaa kohtaamisia ja esitellä hevosia muuten kuin urheiluvälineenä. "Hevosella on vabva ja lämmin terapeuttinen, voimauttava, kokoava sekä ybteisöllisesti kannustava merkitys. Hevosta voi myös koskettaa 
ja kuunnella kävelemisen ja keskustelun aikana. Kavionkopse rauboittaa ja rytmittää ajattelua."

(Hevostilan innovaatiosetelihakemus)

Syksyn 2019 aikana on järjestetty useita pieniä hörinähetkiä ja kaksi isompaa tapahtumaa. Hevoshaan avajaisiin osallistui noin 200 asukasta. Syyshörinät-tapahtuman hevostila järjesti yhteistyössä Vuoreksen asukasyhdistyksen, koulun ja Mannerheimin Lastensuojeluliiton kanssa. Tapahtumassa vieraili päivän aikana 500 kaupunkilaista. Kiinnostusta siis on, ja hevostilalliset ovat kokeneet, että hevoset on toivotettu tervetulleiksi puistoon. Etukäteen pelätyt ongelmat, puistokäytävien kuluminen ja se, ettei hevosia saisi tuoda puistoon kaupungin toimijoiden tai puiston käyttäjien mielestä, eivät ole toteutuneet. Nämä kokemukset puoltavat rohkeaa kokeilemista ja uusia avauksia. Kaupunki osoitti hevoshaan muotoilussa joustavuutta, joka on aiemmissa tutkimuksissa nostettu yhteiskehittämisen onnistumisen edellytykseksi (Voorberg ym. 2015). Hevostilan edustaja arvioi myös, että Vuores on niin uusi asuinalue, ettei sinne ole muodostunut tiukkoja sosiaalisia normeja vaan ilmapiiri on suvaitsevainen. Emme ole vielä keränneet hevoshaan toimintaan osallistuneiden kaupunkilaisten kokemuksia.

Biosuodattimeen ja jäljempänä esiteltävään viherkattoon verrattuna hevoshaka saatiin toteutettua suoraviivaisemmin, koska vastuu oli hevostilalla ja kaupungin rooli pieneni aloitteen teon jälkeen rahoittajaksi ja kannustajaksi. Hevostila oli sitoutunut avaintoimija, joka halusi ja pystyi edistämään projektia. Puisto on kaupungin näkökulmasta yksinkertainen tila, koska se on viheralueyksikön hallinnassa ja ratkaisuja ei tarvitse avata yksiköiden väliselle neuvottelulle. Kokeilun etenemistä helpotti myös sen pieni mittakaava ja rajatut tavoitteet. Näkemyserojakin kuultiin, kun EU-projektin taholta arvioitiin, ettei hevoshaka olisi luontopohjainen ratkaisu. Pienimuotoisuuden ja aktiivisten toimijoiden ansiosta sen toteutus kuitenkin sallittiin. Hevoshaka ei olisi syntynyt ilman ulkoista rahoitusta, mutta nyt kun toiminta on saatu alkuun, toivomme sen kehittyvän ilman julkisen sektorin suuria panostuksia. Keskusteluyhteys on kuitenkin tärkeä säilyttää, jotta luottamus säilyy eivätkä tulkinnat esimerkiksi kaupungista kieltävänä auktoriteettina vahvistu ja haittaa muiden toimijoiden aloitteellisuutta.

Avustusta haettiin vähemmän kuin innovaatioseteleihin oli budjetoitu. Innovaatioseteleitä markkinoitiin laajasti, joten tiedon puutteesta vähäinen hakuinto tuskin johtui. Syynä voi olla esimerkiksi Vuoreksen uudehkot pihat, yhteisten alueiden hoidon ulkoistaminen huoltoliikkeille tai kiireinen elämäntapa. Myös osaamisen puute pihasuunnittelusta tai vieras termi, luontopohjainen ratkaisu, saattoivat vaikuttaa. Toisaalta niillä, jotka hakivat, on kohteiden etenemisen perusteella kykyä toteuttaa pilotit laadukkaasti ja yhteisöllisesti.

Innovaatiosetelikokeilu on rohkaiseva avaus muiden toimijoiden kuin kaupungin aikaisempaa suuremmasta roolista ja johtajuudesta luontopohjaisten ratkaisujen kehittämisessä. Hevostila toi hevoshakaan eläimiä ja tarinan paikan historiasta, mikä ei olisi onnistunut kaupunkivetoisesti. Innovaatioseteliin perustuvaa kokeilua on hyödyllistä jatkaa alueilla, joilla luontopohjaisia ratkaisuja erityisesti tarvitaan esimerkiksi päästöjen hallintaan, viihtyisyyden parantamiseen tai luonnon saavuttamisen helpottamiseen (den Bosch \& Ode Sang 2017). Kehitystarvetta voisi olla vanhoissa lähiöissä tai tiiviissä keskustassa. Paikallista osaamista kehityskohteiden tunnistamisessa voitaisiin hyödyntää avaamalla innovaatiosetelihaku kaikille kaupunkilaisille. Kokemustemme mukaan ongelmia, ratkaisuja tai kohteita ei kannata määritellä ylhäältä käsin.

\section{Viherkatto}

Viherkattojen rakentamisen taustalla on kaupunkien kasvu ja tiivistyminen, joiden seurauksena luonnontilaiset alueet vähenevät ja pinnoitetut alueet lisääntyvät. Samalla ymmärrys kaupunkiluonnon merkityksestä on lisääntynyt ja halutaan uudenlaista kaupunkivihreää - esimerkiksi viherkattoja - viivyttämään hulevesiä, lisäämään hyvinvointia ja tarjoamaan elinympäristöjä kasveille ja eläimille. Tampereen kaupunki ohjaa yksityistä 


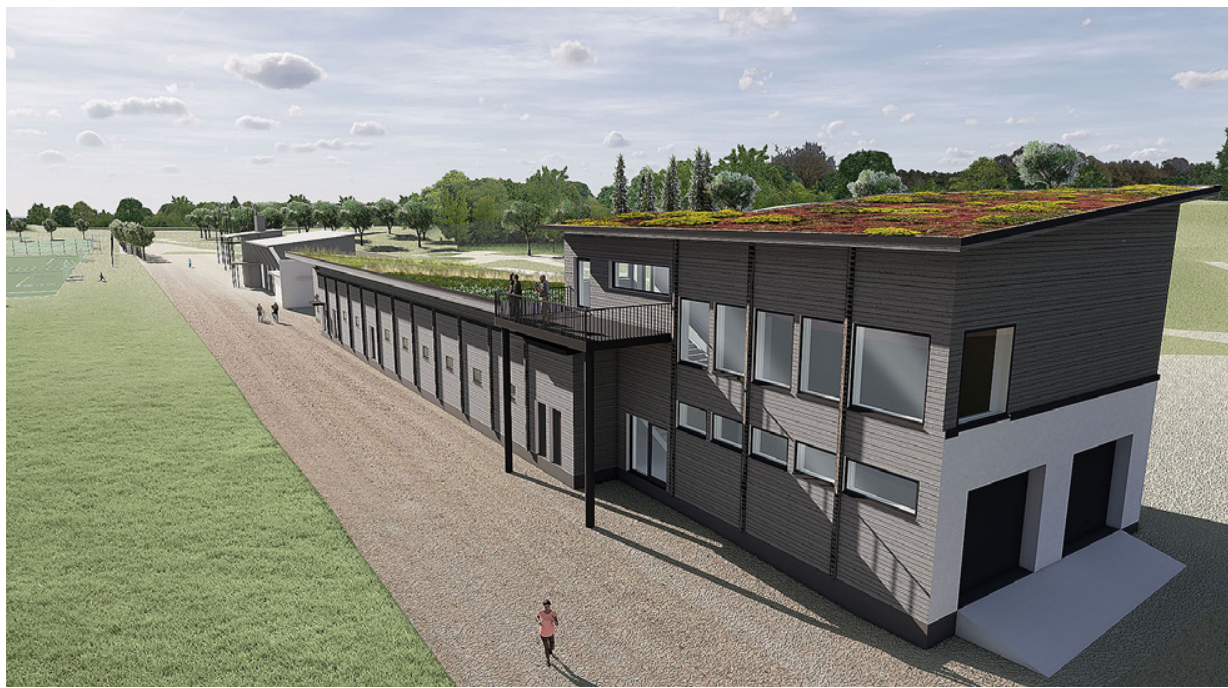

Kuva 3. Havainnekuva niitty- ja ketokatosta Kaupin huoltorakennukseen (Arkkitehdit Kontukoski Oy).

Picture 3. Illustration of a meadow on the rooftop.

rakentamista viherkattojen toteutukseen tietyissä kohteissa, mutta kaupungin omistamissa rakennuksissa niitä ei vielä juuri ole. Poikkeuksen tekee Tampereen Tilakeskuksen liikelaitoksen vuonna 2008 rakennuttama ja omistama Koukkuniemen ravinto- ja huoltokeskuksen viherkatto (Mesimäki ym. 2015). Unalab-hankkeessa valmisteltu julkisen rakennuksen viherkattokokeilu liittyy kaupungin orastavaan pyrkimykseen kehittyä suunnannäyttäjäksi. Viherkattopilotille on etsitty kohdetta, mutta vielä sitä ei ole löytynyt. Kuvassa 3 on arkkitehdin havainnekuva Rambollin Kaupin huoltorakennukseen suunnittelemasta viherkatosta.

Viherkatto on ollut poikkeuksellisen vaativa pilotti, koska sen suunnittelussa tarvitaan ympäristöalan osaamisen yhdistämistä rakennusalan osaamiseen (ks. myös Mesimäki ym. 2015). Tartuimme haasteeseen järjestämällä ylimääräisen viherkattotyöpajan asiantuntijoille, perustamalla ohjausryhmän (Taulukko 1), teettämällä selvityksiä ja neuvottelemalla kaupungin yksiköiden kanssa enemmän kuin muiden pilottien yhteydessä.

Pilottiprojektin alkuperäisissäkin suunnitelmissa ollut viherkatto sai tukea yhteiskehittämisen työpajoissa, kun osallistujat ideoivat uutta kaupunkivihreää tiiviiseen ympäristöön sekä julkisten ja yksityisten alueiden yhdistymistä sini-vihreäksi verkostoksi. Ohjausryhmätyössä ja asiantuntijatyöpajassa rakennusliikkeet nostivat viherkaton tavoitteeksi lisäarvon tuottamisen asukkaille. Hulevesien viivytys on jo tunnistettu viherkattojen hyöty, mutta asukkaille tuotettava lisäarvo nähtiin tärkeäksi investointeihin ohjaavaksi tekijäksi. Viherrakentamisen asiantuntijat ja viherkattotutkija puolestaan nostivat työskentelyn aikana esiin tarpeen kokeilla katolla paikallisia kasvilajeja markkinoilla olevien yksipuolisten maksaruohomattojen sijaan.

Sopivan rakennuksen valinta alkoi siitä, että Hiedanrannan kehitysohjelman, kaupungin kiinteistötoimen ja Unalabin edustajat sopivat keväällä 2018 viherkattokokeilusta Hiedanrannan vanhaan vedenpuhdistamoon. Kyseessä on yksi alueen vanhimmista rakennuksista, joka on sortumisvaarassa ja siten peruskorjauksen tarpeessa. Kohteeseen laadittiin alustavat suunnitelmat puutarhamaisesta viherkatosta ja kustannusarvio. Sitten kaupunki sai vedenpuhdistamosta ostotarjouksen ja viherkattosuunnitelmista luovuttiin. Tämän jälkeen on teetetty alustavat suunnitelmat ja kustannusarviot vielä alueen kahteen muuhun vanhaan halliin. Arvioiden mukaan Hiedanrannan vanhoihin tehdasrakennuksiin on liian kallista rakentaa viherkatto. Viherkaton toteutusta Hiedanrantaan haittasivat 
myös hallien korjaussuunnitelmien ja rahoittajien puuttuminen. Vaikeuksia lisäsi se, että Unalabin hakuvaiheessa ei ollut osattu sitouttaa kaikkia keskeisiä kaupungin yksiköitä viherkattokokeiluun ja sisällyttää sitä heidän investointisuunnitelmiinsa. Näin ollen kokeilun toteutuminen jäi kiinteistötoimen joustavuuden varaan, eikä heitä houkuttanut ajatus "märästä mullasta katolla".

Luontopohjaisen ratkaisun onnistumiseen tarvittava yhteinen näkemys ja kaupungin sisäinen tahtotila (Nesshöver ym. 2017; Paloniemi 2019a) olivat siis kadoksissa. Lopulta monivaiheisten neuvottelujen tuloksena eri yksiköiden viranhaltijat päättivät lisätä viherkattokokeilun Kaupin virkistys- ja ulkoilualueen huoltorakennuksen hankesuunnitelmaan keväällä 2019. Huoltorakennusta pidettiin sopivana kohteena, koska siitä tulee asuintalojen lailla lämmitetty, mutta siellä ei kuitenkaan viivytä pitkään. Lämmin rakennus olisi askel eteenpäin autokatosten viherkatoista, jotka ovat jo yleisiä. Huoltorakennuksen pukuhuoneissa käydään nopeasti, jolloin viherkaton pelätyt kosteusja sisäilmariskit pystyttiin hyväksymään. Lisäksi huoltorakennuksen toteutusaikataulu sopi projektin aikatauluun. Viherkaton kustannusarvioksi laskettiin 225000 euroa. Tästä niittymäisen viherkaton osuus on 90000 , mittausten 15000 , katon painosta johtuvat rakenteelliset lisäkustannukset 74000 ja viherkaton osuus suunnittelu- ja rakennuttamiskuluista sekä hankevaraus 46000 euroa.

Valmistelemamme Kaupin huoltorakennuksen viherkatto hylättiin poliittisessa päätöksenteossa syksyllä 2019. Viherkatto poistettiin huoltorakennuksen suunnitelmista, koska sitä pidettiin kalliina ja paikkaa syrjäisenä. Aamulehti kirjoitti uutisessaan 23.9.2019 Kaupin huoltorakennuksesta ja viherkaton lautakunnassa herättämästä keskustelusta seuraavasti. "Asian esittelijä, konsernijobtaja Juba Yli-Rajala sanoo, että viberkattokokeilua pidetä̈n byvänä asiana, mutta kobdetta on syytä barkita vielä. - Tuntun bullulta, että kokeilu toteutettaisiin keskellä Kaupin vihreyttä, Yli-Rajala sanoo.” Sijainnin kritisointi viittaa siihen, ettei ajatus varovaisesta kokeilusta Kaupin huoltorakennuksessa välittynyt poliittiseen päätöksentekoon. Pitkälle valmisteltu viherkatto sysäsi kuitenkin keskustelua eteenpäin. Yhteistä näkemystä on ehtinyt muodostua kaupungin sisällä sen verran, että uutta kohdetta viherkatolle etsitään edelleen.

\section{”-Jos kokeilu halutaan keskeisempään rakennukseen, sellainen voidaan etsiä. En pidä tätä mitenkään kynnyskysymykesenä. Meillä on useita rakennushankkeita, jotka ovat sunnnittelussa sellaisessa vaiheessa, että siellä näitä valintoja tehdään, sanoo Tampereen kaupungin kiinteistöjobtaja Virpi Ekholm." (Aamulehti 23.9.2019)}

\section{Johtopäätökset}

Pilottiprojektin sisältä käsin saimme vastauksia siihen, kuinka yhteiskehittäminen palvelee yhdessä oppimista luontopohjaisten ratkaisujen suunnittelussa ja toteutuksessa. Tutkimuksemme valottaa myös eri menetelmien soveltuvuutta yhteiskehittämisessä. Tiivistäen tämän tapaustutkimuksen tulos on, että yhdessä oppiminen on yhteiskehittämisen tärkein tavoite ja saavutus, koska se mahdollistaa osallistujien tasavertaisen kohtaamisen. Lisäksi yhdessä oppimisen nostaminen tavoitteeksi luo tilaa luontopohjaisten ratkaisujen monimutkaisuuden hallinnalle. Parhaita tuloksia kohteiden konkreettisesta edistämisestä saimme pienillä aloitteilla ja kokoonpanoilla. Avoimeksi jäivät vielä keinot keskustella aidosti kaupungin isoista suunnitteluperiaatteista.

Yhteiskehittämisen tavoite voi olla yhdessä tekeminen (von Hippel \& Tyre, 1995), jolloin ihmiset työskentelevät yhdessä ja kehittävät tuotetta tai palvelua. Se voi olla myös yhdessä oppiminen, jolloin ihmiset tekevät yhteistyötä luodakseen tietoa, oppiakseen toisiltaan ja verkostoituakseen (Puerari ym. 2018). Usein näihin molempiin tavoitteisiin pyritään yhtä aikaa, mutta toinen tavoitteista voi olla hallitseva (Puerari ym. 2018). Vaikka 
pilottiprojektissa tavoitteena oli myös konkreettisten kohteiden yhdessä tekeminen, vaikuttavuudeltaan yhdessä oppiminen nousi merkittävämpään asemaan. Projektissa toteutetut kohteet olivat pienimuotoisia. Niiden suunnittelusta, rakentamisesta, huollosta ja seurannasta vastasivat ja vastaa kaupunki yhdessä ulkopuolisten asiantuntijoiden kanssa. Työpajojen, asukastilaisuuksien ja muun joustavan vuorovaikutuksen tuloksena on kuitenkin syntynyt yhteistyöverkostoja, luottamussuhteita ja uutta tietoa luontopohjaisten ratkaisujen sovittamisesta kaupunkiin. Näiden avulla on mahdollisuus synnyttää uusia luontopohjaisia ratkaisuja huomattavasti suuremmassa mittakaavassa kuin nyt toteutetut kohteet. Yhdessä oppiminen onkin nostettu yhteiskehittämisen merkittävimmäksi saavutukseksi (Prahalad \& Ramaswamyn 2004) ja näkemyksemme mukaan se luo pohjaa myös yhdessä tekemiselle.

Tulostemme perusteella yhdessä oppiminen kannattaa ottaa luontopohjaisten ratkaisujen tavoitteeksi yhteiskehittämiseen perustuvissa hankkeissa. Luontopohjaisten ratkaisujen luonteeseen kuuluu monimutkaisuus (Nesshöver 2017), jonka hallinnassa yhdessä oppiminen on keskeistä. Kun yhdessä oppiminen tehdään näkyväksi, saadaan suunnitteluun lisää vapauksia ja mahdollisuuksia esimerkiksi monitahoisten lähtötietojen keräämiseen, ja korjauksetkin hyväksytään osana oppimisprosessia. Joshin (2018) mukaan osallistujilla tulisi olla yhteiskehittämisessä yhtäläiset resurssit ja heidän tulisi puhua samaa kieltä pyrkiessään kohti yhteistä tavoitetta tai arvoa. Kokemuksemme mukaan yhteisen vision luominen onkin hyödyllistä asettaa yhdessä oppimisen tavoitteeksi luontopohjaisten ratkaisujen yhteiskehittämisessä. Näin osallistujat ovat yhdenvertaisempia verrattuna siihen, että tavoitteena on konkreettinen toteutussuunnittelu. Jos keskitytään vain toteutussuunnitteluun, asiantuntijoiden näkemyksille tulee helposti liikaa painoarvoa.

Yhdessä oppimisen lisäksi saimme jonkin verran kokemusta myös luontopohjaisten ratkaisujen yhdessä tekemisestä. Siinä pienet aloitteet ja kokoonpanot osoittivat voimansa. Kaikissa projektin kokeiluissa kaupunkiorganisaation ulkopuoliset toimijat osoittivat kykyä tehdä aloitteita ja muotoilla luontopohjaisia ratkaisuja. Tämän kyvykkyyden käyttöönotossa laajoja työpajoja paremmin toimivat pienet kohtaamiset, joissa oli rajattu tavoite ja osallistujaryhmä. Suhtaudummekin kriittisesti alustamaisuuden (Brink \& Wamsler 2018) ja laajan sidosryhmäyhteistyön (Chronéer ym. 2019) hyötyihin luontopohjaisten ratkaisujen käytännön toteutuksessa. Brink ja Wamsler (2018) esittävät, että luontopohjaiset ratkaisut voivat toimia alustana, joka yhdistää paitsi yhteiskehittämiseen osallistuvia myös erilaisia ongelmia. Me havaitsimme luontopohjaisissa ratkaisuissa saman toimijoita ja ongelmia kokoavan voiman. Se osoittautui hyödylliseksi alkuvaiheen yhdessä oppimisessa ja yhteisen vision hahmottelussa. Emme kuitenkaan saaneet näyttöä siitä, että alustamaisuus tai laaja yhteiskehittäminen edistäisi toteutusta. Päinvastoin, laajat suunnitteluryhmät, joissa oli myös löyhästi sitoutuneita toimijoita, vaikeuttivat toteutusta. Raymond ym. (2017) ja Brink ja Wamsler (2018) tuovat esille kaupunkisuunnittelijoiden ennakkoasenteen, jossa aito yhteiskehittäminen nähdään kaupunkisuunnittelun hidasteeksi. Kokemuksemme mukaan tilanne oli monesti juuri ennakkoasenteen mukainen ainakin toteutusvaiheessa ja nykyisillä yhteiskehittämisen menetelmillä. Toteutusta ei kuitenkaan hidastanut kansalaisosallistuminen vaan kaupunkikehitystä ohjaavien instituutioiden välinen kitka.

Kokeilimme erilaisia luovia yhteiskehittämisen menetelmiä. Vuorovaikutuksen edistämisessä saimme hyviä kokemuksia maastoon jalkautumisesta eri muodoissaan. Fratzeskakin (2019) mukaan avoin vuorovaikutus kaupunkisuunnittelijoiden ja muiden toimijoiden välillä on tarpeen luontopohjaisia ratkaisuja kehitettäessä. Lisäksi kaupunkisuunnittelijoiden pitäisi luovuttaa johtajuutta kaupungin muille toimijoille. Kaupungin rooli voi vaihdella eri vaiheissa prosessia aloitteentekijästä johtajaan, mahdollistajaan ja tiedon jakajaan. Meidänkin tuloksemme tukevat avoimuuden merkitystä. Kun kaupunkisuunnittelijat lähtevät paikan päälle keskustelemaan muiden toimijoiden kanssa, opitaan yhdessä, rakennetaan luottamusta ja saadaan myös käytännön toteutusta eteenpäin. Tässä tutkimuksessa luontopohjaisten ratkaisujen muotoiluun soveltuviksi menetelmiksi osoittautuivat karttapohjainen verkkokysely, kaupunkikävely 
sekä koululaisten luokka- ja maasto-opetus. Hyviksi koettiin myös muiden toimijoiden kuin kaupungin johtajuus, kaupungin ja konsultin roolit kannustajina sekä eri alojen asiantuntijoista koostuvat suunnitteluryhmät. Tämän kaltainen joustava työskentely vaatii kuitenkin uusia resursseja menetelmien kehittämiseen ja projektinhallintaan. Meillä oli projektin kautta resursseja ja innostusta kokeilla luovia menetelmiä. Samalla tavalla myös muualla toteutettujen luontopohjaisten ratkaisujen taustalla on ollut usein sitoutuneita avaintoimijoita, rohkeita kokeiluita, yliopistoyhteistyötä ja hankerahoitusta (Paloniemi 2019a).

Käytännön toimet ja monessa tapauksessa myös oppiminen etenevät joustavimmin pienissä kokoonpanoissa, joissa rakentuu luottamusta toimijoiden välille. Yhteiskehittämisen mittakaava olisi kiinnostava jatkotutkimuksen aihe. Meillä on kokemusta vasta lyhytkestoisesta projektista ja olisi hyvä tutkia mihin pienet aloitteet vievät vuosien kuluessa. Voidaanko pienillä aloitteilla edistää kaupunkien luontopohjaisia ratkaisuja tasapuolisesti, ja toisaalta voivatko ne johtaa korkean tason strategisiin linjanvetoihin?

Yhteiskehittämistyön perusteella näyttää siltä, että kaupungin uusien asuinalueiden sisällä olisi tarpeen säilyttää enemmän luonnontilaisia alueita ja hyödyntää niitä esimerkiksi vesien puhdistuksessa ja viivytyksessä. Rakennetut luontopohjaiset ratkaisut olisivat paikallaan enemmänkin olemassa olevaa kaupunkirakennetta tiivistettäessä. Näin ollen olisi tarpeen tutkia, minkälainen yhteiskehittäminen mahdollistaa keskustelun isoista kaupunkisuunnittelun linjoista, kuten luonnonympäristön säilyttämisestä ja muokkaamisen maltillisuudesta. Kokemuksemme mukaan isojen linjausten muutokset vaativat runsaasti tietopohjaa tuekseen. Paloniemi (2019a) tuo esiin, että päätöksenteon tueksi tarvitaan helposti sovellettavaa ja käytäntöä palvelevaa tietoa erityisesti luonnon monimuotoisuudesta ja terveyshyödyistä. Lisäämme tiedontarpeisiin kustannusten ja hyötyjen vertailun sen välillä, säilytetäänkö luonnon ekosysteemejä vai rakennetaanko keinotekoisia luontopohjaisia ratkaisuja.

Jatkossa olisi tarpeen perustaa luonnontilaisen ympäristön suojelun pilottikohde, jossa tarkasteltaisiin esimerkiksi suoalueen toimintaa hulevesien käsittelyssä ja sen hyötyjä. Tuloksia kannattaisi verrata rakennettuun luontopohjaiseen ratkaisuun sekä perinteiseen putkitusratkaisuun. Tässä yhteydessä tulisi tuoda esille myös kosteiden alueiden rakentamiskustannukset ja rakennustekniset hankaluudet. Lisäksi rakentamisen vaikutukset alapuolisiin vesistöihin, luonnon monimuotoisuuteen ja hiilivarastoon tulisi osoittaa. Päätöksenteon tueksi tarvitaan myös konkreettisia laskelmia luontopohjaisten ratkaisujen pitkän aikavälin yhteiskunnallisesta kannattavuudesta verrattuna perinteisiin putkilinjoihin. Edellä mainittujen seikkojen tutkimiseen sekä keskusteluun nostamiseen vaaditaan eri toimijoiden osaamisen yhdistämistä.

\section{Kiitokset}

Kiitämme yhteiskehittämisen työpajojen vetäjiä Inna Ampujaa, Leeni Herralaa ja Laura Ojasta hyvin jäsennellyistä tulosraporteista. Kiitos professori Jukka Rintalalle, arvioitsijoille ja teemanumeron vierailevalle toimittajalle Ari Jokiselle rakentavista kommenteista. Tutkimus toteutettiin Euroopan komission rahoituksella osana Horisontti 2020 -ohjelmaan kuuluvaa Unalab-projektia (rahoitussopimus nro 730052).

\section{Lähteet}

Aamulehti (2019) Tältä näyttää Kaupin urheilupuistoon suunniteltu arviolta 2,7 miljoonan euron huoltorakennus - viherkatto tosin saatetaan riisua vielä pois. URL: https:/ /www.aamulehti.fi/a/4725088ce933-4f18-b0f0-d608a0233f05 (23.9.2019)

Bonner, A. \& Tolhurst, G. (2002) Insider-outsider perspectives of participant observation. Nurse Researcher 9(4) 7-19. https://doi.org//10.7748/nr2002.07.9.4.7.c6194

Brandsen, T., Steen, T. \& Verschuere, B. (2018) Co-Creation and Co-Production in Public Services: Urgent Issues in Practice and Research. In Brandsen, T., Verschuere, B. \& Steen, T. (eds.) Co-Production and Co-Creation: Engaging Citizens in Public Services, 3-8. Routledge, New York. https://doi.org/10.4324/9781315204956 
Brink, E. \& Wamsler, C. (2018) Collaborative Governance for Climate Change Adaptation: Mapping citizenmunicipality interactions: Collaborative governance for climate change adaptation. Environmental Policy and Governance 28(2) 82-97. https:/ / doi.org/10.1002/eet.1795

Chronéer, D., Ståhlbröst, A. \& Habibipour, A. (2019) Urban Living Labs: Towards an Integrated Understanding of their Key Components. Technology Innovation Management Review 9(3) 50-62. http://doi.org/10.22215/ timreview/1224

Coghlan, D. (2007) Insider action research: opportunities and challenges. Management Research News 30(5) 335-343. http://doi.org/10.1108/01409170710746337

Eggermont, H., Balian, E., Azevedo, J.M.N., Beumer, V., Brodin, T., Claudet, J., Fady, B., Grube, M., Keune, H., Lamarque, P., Reuter, K., Smith, M., van Ham, C., Weisser, W.W. \& Le Roux, X. (2015) Nature-based Solutions: New Influence for Environmental Management and Research in Europe. GAIA - Ecological Perspectives for Science and Society 24(4) 243-248. https:// doi.org/10.14512/gaia.24.4.9

Franz, Y., Tausz, K., \& Thiel, S-K. (2015) Contextuality and Co-Creation Matter: A Qualitative Case Study Comparison of Living Lab Concepts in Urban Research. Technology Innovation Management Review 5(12) 48-55. http://doi.org/10.22215/timreview/952

Frantzeskaki, N. (2019) Seven lessons for planning nature-based solutions in cities. Environmental Science and Policy 93 101-111. https://doi.org/10.1016/j.envsci.2018.12.033

Joshi, s. (2018) D1.1 Co-creation Framework - building a sustainable ecosystem. Co-inform -hankkeen väliraportti. URL: https://coinform.eu/wp-content/uploads/2019/02/D1.1-H2020-Co-Inform-Cocreation-Framework.pdf

Kujala, J., Lehtimäki, H. \& Freeman, R. E. (2019) A stakeholder approach to value creation. In Kangas, A., Kujala, J., Heikkinen, A., Lönnqvist, A. \& Laihonen, H. (eds.) Leadership for Change, 123-143. Tampere University Press, Tampere. URL: https://blogs.uta.fi/leadershipforchange/lfc-book/leading-change-ina-complex-world/

Leminen, S., Rajahonka, M., \& Westerlund, M. (2017) Towards Third-Generation Living Lab Networks in Cities. Technology Innovation Management Review 7(11) 21-35. https://doi.org/10.22215/timreview/1118

Maes, J. \& Jacobs, S. (2017) Nature-Based Solutions for Europe's Sustainable Development. Conservation Letters 10(1) 121-124. https://doi.org/10.1111/conl.12216

Mesimäki, M. H., Nieminen, H. \& Lehvävirta, R. S. (2015) Uudenlaisen vihreän infrastruktuurin toteutumisen reunaehdot rakentamisen prosesseissa - tapauksena viherkatot. Ybdyskuntasuunnittelu 53(3). URL: http:// www.yss.fi/journal/uudenlaisen-vihrean-infrastruktuurin-toteutumisen-reunaehdot-rakentamisenprosesseissa-tapauksena-viherkatot/

Nesshöver, C., Assmuth, T., Irvine, K.N., Rusch, G.M., Waylen, K.A., Delbaere, B., Haase, D., Jones-Walters, L., Keune, H., Kovacs, E., Krauze, K., Külvik, M., Rey, F., van Dijk, J., Vistad, O.I., Wilkinson, M.E. \& Wittmer, H. (2017) The science, policy and practice of nature-based solutions: An interdisciplinary perspective. Science of the Total Environment 579 1215-1227. https://doi.org/10.1016/j.scitotenv.2016.11.106

Paloniemi, R. (2019a) Kestävää kaupunkisuunnittelua. Luontopohjaiset ratkaisut maakunnissa ja kunnissa. Valtioneuvoston selvitys ja tutkimustoiminnan julkaisusarja 48, Helsinki. http://julkaisut.valtioneuvosto. $\mathrm{fi} /$ handle/10024/161757

Paloniemi, R. (2019b) Luontopohjaisten ratkaisujen käytännön toteuttaminen maakunnissa ja kunnissa. Valtioneuvoston selvitys ja tutkimustoiminnan julkaisusarja 49, Helsinki. http://julkaisut.valtioneuvosto. $\mathrm{fi} /$ handle/10024/161758

Prahalad, C. K., \& Ramaswamy, V. (2004). Co-creation experiences: The next practice in value creation. Journal of Interactive Marketing 18(3) 5-14. https://doi.org/10.1002/dir.20015

Puerari, E., de Koning, J., von Wirth, T., Karré, P., Mulder, I. \& Loorbach, D. (2018) Co-Creation Dynamics in Urban Living Labs. Sustainability 10(6) 1893. https://doi.org/10.3390/su10061893

Raymond, C.M., Frantzeskaki, N., Kabisch, N., Berry, P., Breil, M., Nita, M.R., Geneletti, D. \& Calfapietra, C. (2017) A framework for assessing and implementing the co-benefits of nature-based solutions in urban areas. Environmental Science and Policy 77 15-24. https://doi.org/10.1016/j.envsci.2017.07.008

Smith, D. E. (2002) Institutional ethnography. In May, T. (ed.) Qualitative research in action, 17-52. Sage, London.

Tuomi, J. \& Sarajärvi, A. (2018) Laadullinen tutkimus ja sisällönanalyysi. Uudistettu laitos. Tammi, Helsinki.

Tuomisaari, J. \& Peltola, T. (2011) Katsaus tiedon etnografioihin: Takametsien tietoyhteiskunta ja luonnonsuojelu. Alue ja Ympäristö 40(1), 53-57. URL: https://aluejaymparisto.journal.fi/article/view/64498

van den Bosch, M. \& Ode Sang, А. (2017) Urban natural environments as nature-based solutions for improved public health - A systematic review of reviews. Environmental Research 158, 373-384. https:// doi.org/10.1016/j.envres.2017.05.040

von Hippel, E. \& Tyre, M.J. (1995) How learning by doing is done: problem identification in novel process equipment. Research Policy 24(1) 1-12. https:/ / doi.org/10.1016/0048-7333(93)00747-H

Voorberg, W.H., Bekkers, V. J. J. M. \& Tummers, L. G. (2015) A Systematic Review of Co-Creation and Co-Production: Embarking on the social innovation journey. Public Management Review 17(9) 1333-1357. https://doi.org/10.1080/14719037.2014.93050 